\title{
Algoritma Nä̈ve Bayes Untuk Klasifikasi Penerima Bantuan Pangan Non Tunai ( Studi Kasus Kelurahan Utama )
}

\author{
Naive Bayes Algorithm For Classification of Non-Cash Food Aid Recipients (Case Study of \\ Utama Village)
}

\author{
Castaka Agus Sugianto ${ }^{1}$, Firdi Rizky Maulana ${ }^{2}$ \\ ${ }^{1,2}$ Program Studi Teknik Informatika - Politeknik TEDC Bandung \\ E-mail: ${ }^{1}$ castaka@poltektedc.ac.id, ${ }^{2}$ firdirizki@ rocketmail.com
}

\begin{abstract}
Abstrak
Kelurahan Utama merupakan instansi pemerintahan di Cimahi Selatan. Kelurahan Utama menjalankan program pemerintah yaitu program Bantuan Pangan Non Tunai, dalam menjalankan program Bantuan Pangan Non Tunai sebagian warga banyak yang mengeluh karena tidak mendapat bantuan, sedangkan ada beberapa warga yang dianggap mampu justru mendapatkan bantuan. Berdasarkan latar belakang tersebut maka Penelitian ini melakukan proses pengolahan data menggunakan data mining untuk mengklasifikasi penerima dan bukan penerima bantuan pangan non tunai dengan metode klasifikasi menggunakan Algoritma Nä̈ve Bayes dan Algoritma Decision Tree sebagai pembanding. Diharapkan data yang dihasilkan dari proses data mining bisa menjadi bahan evaluasi untuk pemerintah. Dalam penelitian ini mengklasifikasi data penerima dan bukan penerima bantuan pangan non tunai menggunakan teknik klasifikasi pada data mining menggunakan Algoritma Nä̈ve Bayes dan Algoritma Decision Tree sebagai pembanding. Model data mining di buat menggunakan RapidMiner, dengan hasil nilai Probabilitas untuk class 'PENERIMA' yaitu 0,481 dengan pembulatan nilai menjadi 0,48 dan nilai Probabilitas untuk class 'Bukan Penerima"' yaitu 0,519 dengan pembulatan nilai menjadi 0,52. Algoritma Nä̈ve Bayes mempunyai tingkat Accuracy sebesar 58,29\%, Precision 92,90\%, Recall 21,84\%, AUC 0,765, F-Measure 34.42\%. Sedangkan algoritma Decision Tree mempunyai tingkat Accuracy sebesar 73,97\%, Precision 85,04\%, Recall 61,92\%, AUC 0,746, F-Measure 71,17\%. Dalam hasil pengujian T-Test antara Algoritma Naive Bayes dan Algoritma Decision Tree didapat alpha $\leq 0.000$, maka dapat disimpulkan pengujian T-Test antara Algoritma Nä̈ve Bayes dan Algoritma Decision Tree hasilnya signifikan.
\end{abstract}

Kata kunci: Kelayakan, Data Mining, Klasifikasi, T-Test, Nä̈ve Bayes, Decision tree

\begin{abstract}
Utama villlage is a government agency in southern cimahi. Utama village run the government program, namely the Non-Cash Food Aid program, in carrying out the Non-Cash Food Aid program, many residents complain that they do not get assistance, while there are some people who are considered able to get help. Based on this background, carry out data processing using data mining to classify recipients and not recipients of non-cash food aid with classification methods using the Naïve Bayes Algorithm and Decision Tree Algorithm as a comparison. It is hoped that the data generated from the data mining process can be an evaluation material for the government. In this study the authors classify recipient data and not recipients of non-cash food aid using classification techniques in data mining using the Nä̈ve Bayes Algorithm and Decision Tree Algorithm as a comparison. The data mining model is made using RapidMiner, with the result that the Probability value for the class "RECEIVER " is 0.481 with rounding the value to 0.48 and the Probability value for the class 'Non Recipient' which is 0.519 with rounding the value to 0.52. The Naïve Bayes algorithm has an Accuracy level of 58.29\%, Precision 92.90\%, Recall 21.84\%, AUC 0.765, FMeasure 34.42\%. While the Decision Tree algorithm has an Accuracy level of 73.97\%, Precision $85.04 \%$, Recall $61.92 \%$, AUC 0.746, F-Measure 71.17\%. In the results of testing the T-Test between the Naive Bayes Algorithm and the Decision Tree Algorithm, alpha $\leq 0.000$ was obtained, it can be
\end{abstract}


concluded that the T-Test between the Naïve Bayes Algorithm and the Decision Tree Algorithm was significant.

Keywords: Feasibility, Data mining, Classification, T-Test, Nä̈ve Bayes, Decision Tree.

\section{PENDAHULUAN}

Masyarakat miskin adalah suatu kondisi dimana fisik masyarakat yang tidak memiliki akses ke prasarana dan sarana dasar lingkungan yang memadai, dengan kualitas perumahan dan pemukiman yang jauh di bawah standar kelayakan serta mata pencaharian yang tidak menentu yang mencangkup seluruh multidimensi, yaitu dimensi politik, dimensi sosial, dimensi lingkungan, dimensi ekonomi dan dimensi aset[1].

Dalam membantu meminimalkan kemiskinan, kementrian sosial membuat program bantuan untuk warga miskin, bantuan yang dibuat kementrian sosial adalah Bantuan Pangan Non Tunai (BPNT). Bantuan Pangan Non Tunai (BPNT) adalah bantuan sosial pangan yang disalurkan dalam bentuk non tunai dari pemerintah kepada Keluarga Penerima Manfaat (KPM) setiap bulannya. Melalui mekanisme uang elektronik yang digunakan hanya untuk membeli bahan pangan di pedagang bahan pangan atau disebut E-warong yang bekerjasama dengan Bank Penyalur [2].

Kelurahan adalah pembagian wilayah administratif di Indonesia di bawah kecamatan. Kelurahan juga mempunyai tugas untuk memberikan pelayanan kepada masyarakat dalam hal pembuatan E-KTP, pembuatan Kartu Keluarga, Akta Kelahiran, dan pengajuan bantuan program dari pemerintah. Salah satu program dari pemerintah adalah program Bantuan Pangan Non Tunai yang di selenggarakan pada tahun 2017 di 44 Kota di Indonesia[1]. Salah satunya adalah Kota Cimahi, dan disebarkan ke beberapa kelurahan yang ada di kota Cimahi, salah satunya adalah Kelurahan Utama.

Kelurahan Utama adalah suatu instansi pemerintahan yang berada di dalam cangkupan Kecamatan Cimahi Selatan, dalam menjalankan tugas sebagai pelayanan publik, Kelurahan Utama memberikan pengajuan dari beberapa Program Pemerintah, seperti Kartu Indonesia Sehat, Kartu Indonesia Pintar, BPJS dan Bantuan Pangan Non Tunai. Salah satu program yang memilik kendala di Kelurahan Utama adalah Program Bantuan Pangan Non Tunai.

Dari hasil final data kependudukan 2017 jumlah warga di Kelurahan Utama sebanyak 36.054 KK yang terbagi dalam $16 \mathrm{RW}$ dan $91 \mathrm{RT}$. Dari data tersebut tercatat jumlah warga miskin (gakin) sebanyak 1086 KK. Dari data warga miskin tersebut, penerima BPNT sebanyak 626 KK.

Dengan adanya masalah tersebut, mengakibatkan adanya ketidak sinkronan penerima BPNT. Masyarakat yang berhak menerima bisa jadi tidak menerima, sedangkan warga yang bukan merupakan warga miskin malah justru menerima BPNT. Jika penerima BPNT jelas terdata dengan baik, serta syarat kelayakan penerimaan BPNT yang terdata dengan baik, maka akan mengurangi ketidaksinkronan penerima BPNT dan juga lebih memudahkan petugas di dalam pembagian BPNT tersebut. Oleh karena itu dibutuhkan analisis terhadap penerima BPNT yang bisa dilakukan dengan berbagai teknik analisis, salah satunya menggunakan teknik data mining.

Data mining adalah suatu cara yang bertujuan dalam penemuan pola secara otomatis atau semi otomatis dari data yang sudah ada di dalam database atau sumber data lain yang dimanfaatkan untuk menyelesaikan suatu masalah melalui berbagai aturan proses [3]. Salah satu teknik data mining adalah fungsi klasifikasi. Fungsi klasifikasi dapat memudahkan mengidentifikasi kelayakan penerima dan bukan penerima BPNT. Teknik klasifikasi adalah teknik pembelajaran yang digunakan untuk memprediksi nilai dari atribut kategori target [4]. Beberapa Algoritma dalam klasifikasi diantaranya adalah C4.5, ID3, K-Nearest Neighbor Classifier, Naive Byase Classifier, SVM, dan ANN [5].

Nä̈ve bayes Classifier merupakan salah satu metode yang digunakan dalam data mining yang didasarkan pada keputusan bayes. Nä̈ve bayes Classifier memiliki kemampuan klasifikasi seperti metode decision tree dan neural network. metode ini dapat digunakan untuk memprediksi probabilitas keanggotaan suatu class [6]. Naïve Bayes merupakan algoritma klasifikasi yang ada dalam teknik data mining yang menggunakan teori bayes [7]. Nä̈ve Bayes memiliki tingkat akurasi yang lebih baik dibanding model classifier lainnya [8]. Nä̈ve Bayes adalah salah satu algoritma klasifikasi yang simple dan mudah dalam implementasinya [9]. Ketika diuji menggunakan data yang benar algoritma ini sangat efektif, apalagi ketika di kombinasikan dengan pemilihan fungsi, sehingga redudant pada 
data dapat dikurangi [10], Algoritma naïve bayes memiliki performance yang bagus ketika digabungkan dengan metode clustering [11]. Nä̈ve Bayes sudah terbukti memiliki akurasi yang tinggi dibandingkan dengan algoritma support vector machine[12]. Hal ini sejalan dengan penelitian terdahulu dalam memprediksi data customer dengan metode naïve bayes mendapatkan hasil yang baik [13]. Maka penelitian ini akan menggunakan data mining teknik klasifikasi dengan algoritma Naïve Bayes.

Selain itu, penelitian yang sudah dilakukan oleh Andi Bekto Rahardjo [14] Penerapan Data Mining untuk Mengklasifikasi Penerima dan Bukan Penerima Kartu Identitas Miskin (KIM), hasilnya dari data yang berjumlah 240 record dan 15 atribut menghasilkan tingkat akurasi tertinggi yaitu 93,06\%. Penelitian lain mengenai klasifikasi masyarakat miskin di wilayah pemerintahan Kecamatan Tibawa Kab. Gorontalo mendapat hasil akurasi sebesar 73\% atau termasuk dalam kategori Good. Sementara nilai Precision sebesar 92\% dan Recall sebesar 86\%.[15] Sedangakan yang hamper sama namun beda algoritma yang digunakan yaitu K-nearest Neighbor untuk mengklasifikasikan penerima Kartu Indonesia menggunakan variabel yang sudah ditentukan mendapatkan hasil yang baik.[16]. Senada yang dilakukan oleh Yeni Magfiroh, algoritma Naive Bayes memiliki performance yang tinggi[17].

\section{METODE PENELITIAN}

Ada 9 (sembilan) tahapan yang akan dilakukan Penelitian ini. Diantaranya:

\subsection{Menentukan Masalah}

Menentukan Masalah yang merupakan proses awal dalam penelitian ini. Proses ini sudah dijelaskan pada latar belakang mengenai klasifikasi penerima dan bukan penerima bantuan pangan non tunai di kelurahan utama.

\subsection{Menentukan Tujuan dan Ruang Lingkup}

Menentukan tujuan dan ruang lingkup merupakan apa yang ingin di capai dalam penelitian, serta batasan yang dipakai agar penelitian tidak terlalu melebar.

\subsection{Mencari Literature}

Mencari literature merupakan mencari informasi yang berkaitan dengan penelitian seperti data mining, algoritma Nä̈ve Bayes, C4.5, dan klasifikasi kelayakan.

\subsubsection{Pencarian Literature}

Metode pengumpulan literature mempunyai peranan penting dalam penelitian ini, karena dari metode pengumpulan data akan menghasilkan informasi untuk prediksi yang akan dihasilkan dan di kumpulkan untuk mendukung selama proses penelitian.

\subsubsection{Study Pustaka}

Metode yang di lakukan dengan mencari sumber dari buku-buku, jurnal, dan media internet yang berhubungan dengan penelitian ini. Data-data yang kumpulkan dari hasil studi pustaka adalah:

1. Materi tentang data mining.

2. Pengumpulan jurnal-jurnal yang berhubungan dengan data mining, Algoritma Nä̈ve Bayes, Algoritma C4.5.

3. Pencarian indikator yang sesuai.

4. Pencarian teori-teori yang di butuhkan yang berkaitan dengan penelitian ini.

\subsection{Menentukan Indikator Data}

Indikator yang di gunakan dalam data pada penelitian menggunakan indikator yang di gunakan oleh Badan Pusat Statistik Kota Cimahi. 


\subsection{Pengumpulan Data}

Proses pengumpulan data dilakukan dengan cara mengambil data dari daftar kolektif hasil Penerima Bantuan Pangan Non Tunai Kelurahan Utama dan data hasil kuisioner PPLS ( Program Perlindungan Sosial ) Tahun 2011.

\subsection{Preparasi Data}

Proses preparasi data yang di lakukan adalah dengan mengubah dari data hard copy kedalam format excel.

\subsubsection{Data Yang Digunakan}

Data yang di gunakan dalam penelitian ini di ambil dari hasil final data kependudukan 2017 jumlah warga di Kelurahan Utama sebanyak 36.054 KK yang terbagi dalam 16 RW dan 91 RT. Dari data tersebut tercatat jumlah warga miskin (gakin) sebanyak 1086 KK. Dari data warga miskin tersebut, penerima BPNT sebanyak $626 \mathrm{KK}$. Data tersebut di ambil dari awal bulan desember 2017 sampai bulan Mei 2018. Data dalam penelitian ini akan di uji dengan Algoritma Nä̈ve bayes dan di bandingan dengan dengan algoritma $C 4.5$ dan di validasi menggunakan cross validation,T-test, serta Anova. Berikut dataset daftar kolektif hasil penyebaran Kuisioner bisa di lihat pada tabel 1.

Gambar 1 Tabel Dataset Data Kuisioner PPLS Tahun 2011

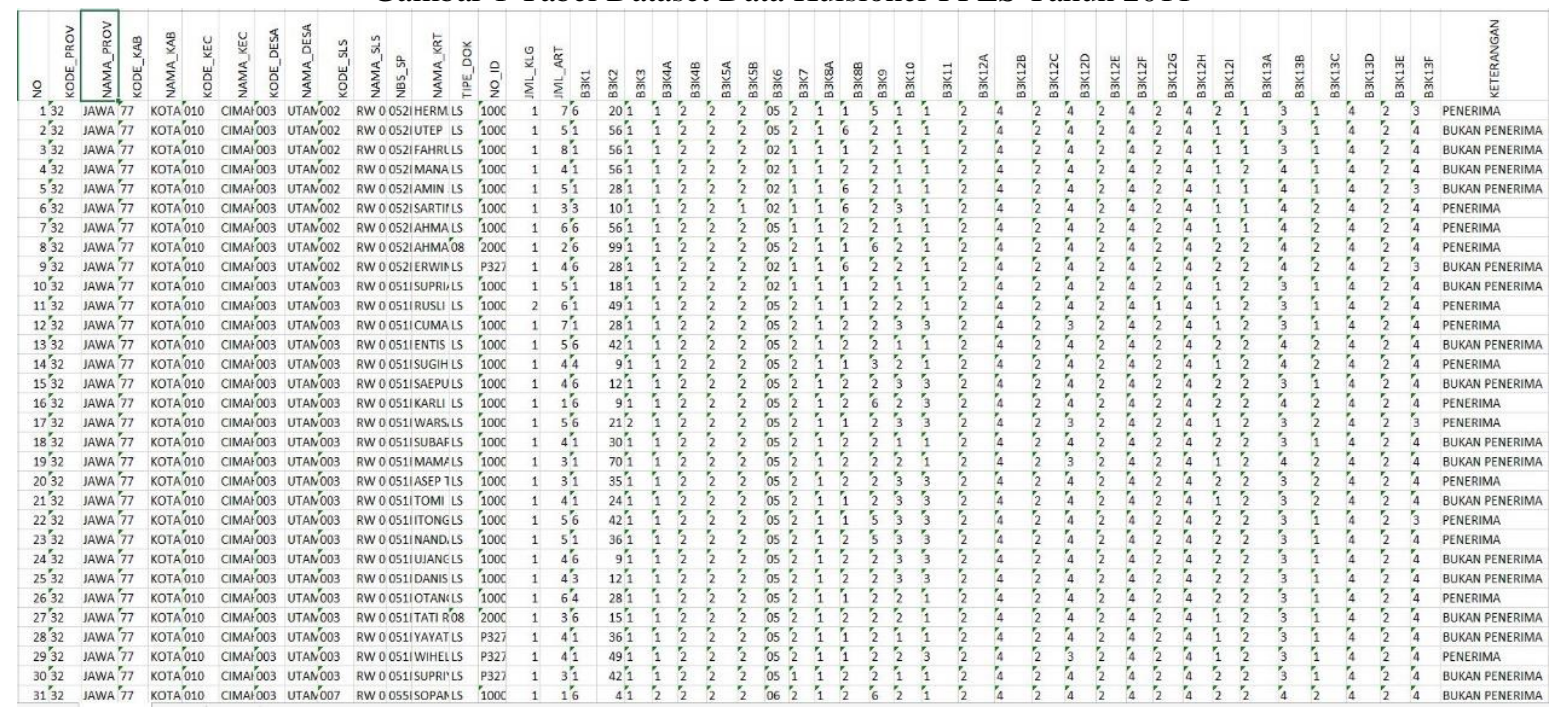

\subsubsection{Proses Cleansing Data}

Sebelum dilakukan proses data mining pada proses ini dataset akan di reparasi yaitu menghilangkan field yang tidak perlu di pakai ketika proses data mining. Dalam penelitian ini padaawalnya terdapat 47 field kemudian setelah di lakukan cleansing data menjadi 31 field adapun fieldnya bisa di lihat pada Tabel 2 .

Tabel 1 Tabel Keterangan Field

\begin{tabular}{|c|c|c|c|}
\hline No & Atribut & Jenis Data & Type Data \\
\hline 1 & NO & Integer & Id \\
\hline 2 & NAMA_KRT & Varchar & Attribute \\
\hline 3 & JML_KLG & Integer & Attribute \\
\hline 4 & JML_ART & Integer & Attribute \\
\hline 5 & B3K1 & Integer & Attribute \\
\hline
\end{tabular}




\begin{tabular}{|c|c|c|c|}
\hline 6 & B3K2 & Integer & Attribute \\
\hline 7 & B3K3 & Integer & Attribute \\
\hline 8 & B3K4A & Integer & Attribute \\
\hline 9 & B3K4B & Integer & Attribute \\
\hline 10 & B3K5A & Integer & Attribute \\
\hline 11 & B3K5B & Integer & Attribute \\
\hline 12 & B3К6 & Integer & Attribute \\
\hline 13 & B3K7 & Integer & Attribute \\
\hline 14 & B3K8A & Integer & Attribute \\
\hline 15 & B3K8B & Integer & Attribute \\
\hline 16 & B3K9 & Integer & Attribute \\
\hline 17 & B3K10 & Integer & Attribute \\
\hline 18 & B3K11 & Integer & Attribute \\
\hline 19 & B3K12A & Integer & Attribute \\
\hline 20 & B3K12D & Integer & Attribute \\
\hline 21 & B3K12E & Integer & Attribute \\
\hline 22 & B3K12G & Integer & Attribute \\
\hline 23 & $\mathrm{~B} 3 \mathrm{~K} 12 \mathrm{H}$ & Integer & Attribute \\
\hline 24 & B3K12I & Integer & Attribute \\
\hline 25 & B3K13A & Integer & Attribute \\
\hline 26 & B3K13B & Integer & Attribute \\
\hline 27 & B3K13C & Integer & Attribute \\
\hline 28 & B3K13D & Integer & Attribute \\
\hline 29 & B3K13E & Integer & Attribute \\
\hline 30 & B3K13F & Integer & Attribute \\
\hline 31 & KETERANGAN & Varchar & Nominal \\
\hline
\end{tabular}

Variabel yang di pakai dalam pengumpulan data menggunakan Variabel dari Badan Pusat Statistik, pemilahan dan pengkodean Field dapat dijelaskan dengan di keterangan tabel 3.

Tabel 2 Keterangan Variabel Data

\begin{tabular}{|c|l|c|}
\hline $\begin{array}{c}\text { Blok } \\
\text { Keterangan }\end{array}$ & \multicolumn{1}{|c|}{ Variabel Data } & Nama Field \\
\hline 1. & $\begin{array}{l}\text { Status Penguasaan Bangunan Tempat Tinggal yang } \\
\text { ditempati }\end{array}$ & B3K1 \\
\hline 2. & Luas Lantai.... $m^{2}$ & B3K2 \\
\hline
\end{tabular}




\begin{tabular}{|c|c|c|}
\hline 3. & Jenis Lantai Terluas & B3K3 \\
\hline 4. & $\begin{array}{l}\text { a. Jenis Dinding Terluass } \\
\text { b. Jika 4a Berkode } 1 \text { atau 2, Kondisi Dinding }\end{array}$ & $\begin{array}{l}\text { B3K4A } \\
\text { B3K4B }\end{array}$ \\
\hline 5. & $\begin{array}{l}\text { a. Jenis Lantai Terluas. } \\
\text { b. Jika 5a berkode } 1,2,3,4 \text { atau } 5 \text { Kondisi Atap }\end{array}$ & $\begin{array}{l}\text { B3K5A } \\
\text { B3K5B }\end{array}$ \\
\hline 6. & Sumber Air Minum & B3K6 \\
\hline 7. & Cara Memperoleh Air Minum & B3K7 \\
\hline 8. & $\begin{array}{l}\text { a. Sumber Penerangan Utama } \\
\text { b. Jika Listrik PLN }(8 a=1) \text {, daya terpasang }\end{array}$ & $\begin{array}{l}\text { B3K8A } \\
\text { B3K8B }\end{array}$ \\
\hline 9. & Bahan bakar/energy utama untuk memasak & B3К9 \\
\hline 10. & Penggunaan Fasilitas tempat buang Air Besar & B3K10 \\
\hline 11. & Tempat Pembuangan Akhir Tinja & B3K11 \\
\hline 12. & $\begin{array}{l}\text { Apakah rumah tangga memiliki sendiri asset sebagai } \\
\text { berikut: } \\
\text { a. Mobil. } \\
\text { d. Sepeda Motor. } \\
\text { e. Sepeda. } \\
\text { g. Lemari es/kulkas. } \\
\text { h. Tabung gas } 12 \mathrm{~kg} \text { atau lebih. } \\
\text { i. HP }\end{array}$ & $\begin{array}{l}\text { B3K12A } \\
\text { B3K12D } \\
\text { B3K12E } \\
\text { B3K12G } \\
\text { B3K12H } \\
\text { B3K12I }\end{array}$ \\
\hline 13. & $\begin{array}{l}\text { Apakah rumah tangga menjadi peserta program berikut: } \\
\text { a. Program Keluarga Harapan (PKH) } \\
\text { b. Beras Untuk Orang Miskin (Raskin) } \\
\text { c. Jaminan Kesehatan Masyarakat (Jamkesmas) } \\
\text { d. Asuransi Kesehatan Lainnya. } \\
\text { e. Jaminan Sosial Tenaga Kerja (Jamsostek). } \\
\text { f. Keluarga Berencana (KB) }\end{array}$ & $\begin{array}{l}\text { B13KA } \\
\text { B13KB } \\
\text { B13KC } \\
\text { B13KD } \\
\text { B13KE } \\
\text { B13KF }\end{array}$ \\
\hline
\end{tabular}

\subsection{Proses dan Hasil}

Proses data mining yang di lakukan menggunakan algoritma Nä̈ve Bayes yang menghasilkan nilai akurasi, dan akan di bandingkan dengan algoritma C4.5 karena algoritma C4.5 merupakan algoritma klasifikasi yang dapat membuat pohon keputusan untuk menghasilkan data.

\subsection{Analisis}

Proses analisis pada penelitian ini mengamati dan menjelaskan hasil dari proses RapidMiner.

\subsection{Penarikan Kesimpulan}

Penarikan Kesimpulan merupakan hasil dari proses pengujian yang telah dilakukan serta hasil analsisi Penelitian ini. 


\section{HASIL DAN PEMBAHASAN}

\subsection{Pengujian Menggunakan Algoritma Nä̈ve Bayes}

Pengujian ini dilakukan untuk mengetahui nilai Accuracy, Precision, Recall, AUC, F-Measure yang keluar serta mengetahui seperti apa hasil Simple Distributor dan Grafik ROC yang akan di hasilkan pada proses data mining.

Berikut adalah hasil pengujian menggunakan Algoritma Nä̈ve Bayes dan menggunakan validasi Cross Validation. Dari Tabel 4. menunjukan bahwa Algoritma Nä̈ve Bayes mendapatkan hasil Accuracy sebesar 58,29\%, Precision 92,90\%, Recall 21,84\%, AUC 0,765, F-Measure 34,42\%.

\begin{tabular}{|l|c|c|c|c|c|}
\hline \multicolumn{7}{|c|}{ Hasil Pengujian Algoritma Naïve Bayes/ } \\
\hline & Accuracy & Precision & Recall & AUC & F-Measure \\
\hline Algoritma Nä̈ve Bayes & $58,29 \%$ & $92,90 \%$ & $21,84 \%$ & 0,765 & $34.42 \%$ \\
\hline
\end{tabular}

Gambar 2 Hasil Pengujian Algoritma Nä̈ve Bayes

Untuk membuktikan hasil klasifikasi penerima Bantuan Pangan Non Tunai, bisa dilakukan dengan perhitungan manual nä̈ve bayes classifier dengan rumus (1) sebagai berikut :

$$
P(C \iota \mid X)=\frac{P(X \mid C \iota) P(C \iota)}{P(X)}
$$

Menghitung jumlah kelas dari klasifikasi yang terbentuk

$\mathrm{C} 1=$ Penerima

$\mathrm{C} 2=$ Bukan Penerima

Perhitungan :

$\mathrm{P}(\mathrm{X} \mid \mathrm{Ci})=\mathrm{P}($ penerima $)=301 / 626=0,481$

$\mathrm{P}(\mathrm{X} \mid \mathrm{Ci})=\mathrm{P}($ bukan penerima $)=325 / 626=0,519$

Perhitungan :

$\mathrm{P}($ hakmilik bangunan="peribadi" $\mid$ penerima $)=98 / 301=0,325$

$\mathrm{P}($ hakmilik bangunan="peribadi" | bukan penerima $)=300 / 325=0,923$

$\mathrm{P}($ luas bangunan="0-50 $\mathrm{m} 2 " \mid$ penerima $)=102 / 301=0,339$

$\mathrm{P}($ luas bangunan="0-50 $\mathrm{m} 2 " \mid$ bukan penerima $)=38 / 325=0,117$

$\mathrm{P}($ jenis lantai bangunan=" $>50 \%$ tanah" $\mid$ penerima $)=108 / 301=0,359$

$\mathrm{P}(\mathrm{jenis}$ lantai bangunan=">50\% tanah" $\mid$ bukan penerima $)=0 / 325=0$

$\mathrm{P}($ sumber air minum="air tidak dilindung" $\mid$ penerima $)=65 / 301=0,216$

$\mathrm{P}($ sumber air minum="air tidak dilindung" $\mid$ bukan penerima $)=30 / 325=0,092$

$\mathrm{P}($ sumber penerangan $=" 450$ watt" $\mid$ penerima $)=207 / 301=0,688$

$\mathrm{P}($ sumber penerangan="450 watt" $\mid$ bukan penerima $)=50 / 325=0,154$

$\mathrm{P}($ bahan bakar="kompor minyak" $\mid$ penerima $)=1 / 301=0,003$

$\mathrm{P}($ bahan bakar="kompor minyak" $\mid$ bukan penerima $)=0 / 325=0$

$\mathrm{P}($ lantai ketersedian $\mathrm{wc}=$ "jamban umum" $\mid$ penerima $)=78 / 301=0,24$ 
$\mathrm{P}($ lantai ketersedian $\mathrm{wc}=$ "jamban umum" $\mid$ bukan penerima $)=0 / 325=0$

$\mathrm{P}($ Kepemilikan Aset="Mobil" $\mid$ penerima $)=1 / 301=003$

$\mathrm{P}($ Kepemilikan Aset $=$ "Mobil" $\mid$ bukan penerima $)=171 / 325=0,526$

$\mathrm{P}($ Kepemilikan Aset=" Sepeda Motor" $\mid$ penerima $)=268 / 301=0,890$

$\mathrm{P}($ Kepemilikan Aset $=$ " Sepeda Motor" $\mid$ bukan penerima $)=290 / 325=0,892$

$\mathrm{P}($ Kepemilikan Aset=" Sepeda" $\mid$ penerima $)=68 / 301=0,226$

$\mathrm{P}($ Kepemilikan Aset $=$ "Sepeda" | bukan penerima $)=17 / 325=0,052$

$\mathrm{P}($ Kepemilikan Aset=" Lemari Es" $\mid$ penerima $)=60 / 301=0,199$

$\mathrm{P}($ Kepemilikan Aset ="Lemari Es" $\mid$ bukan penerima $)=301 / 325=0,926$

$\mathrm{P}($ Kepemilikan Aset $=$ " Tabung Gas $>=12 \mathrm{~kg} " \mid$ penerima $)=6 / 301=0,020$

$\mathrm{P}($ Kepemilikan Aset $=$ "Tabung Gas $>=12 \mathrm{~kg} " \mid$ bukan penerima $)=45 / 325=0,138$

$\mathrm{P}($ Kepemilikan Aset="HP" | penerima $)=301 / 301=1$

$\mathrm{P}($ Kepemilikan Aset $=" H P " \mid$ bukan penerima $)=325 / 325=1$

$\mathrm{P}($ kepesertaan program="PKH" $\mid$ penerima $)=20 / 301=0,066$

$\mathrm{P}($ kepesertaan program="PKH" $\mid$ bukan penerima $)=171 / 325=0,526$

$\mathrm{P}($ kepesertaan program="Raskin" $\mid$ penerima $)=260 / 301=0,864$

$\mathrm{P}($ kepesertaan program="Raskin" $\mid$ bukan penerima $)=0 / 325=0$

$\mathrm{P}($ kepesertaan program="jamkesmas" $\mid$ penerima $)=89 / 301=0,296$

$\mathrm{P}($ kepesertaan program="jamkesmas" $\mid$ bukan penerima $)=312 / 325=0,96$

$\mathrm{P}($ kepesertaan program="Asuransi" $\mid$ penerima $)=5 / 301=0.017$

$\mathrm{P}($ kepesertaan program="Asuransi" | bukan penerima $)=71 / 325=0,218$

$\mathrm{P}($ kepesertaan program="Jamsostek" $\mid$ penerima $)=102 / 301=0.339$

$\mathrm{P}($ kepesertaan program="Jamsostek" $\mid$ bukan penerima $)=210 / 325=0,646$

$\mathrm{P}($ kepesertaan program="KB" $\mid$ penerima $)=296 / 301=0,983$

$\mathrm{P}($ kepesertaan program="KB" $\mid$ bukan penerima $)=305 / 325=0,938$

Mengkalikan semua hasil dari atribut

$\mathrm{P}(\mathrm{X} \mid$ penerima $)=0,325 \times 0,339 \times 0,359 \times 0,216 \times 0,688 \times 0,003 \times 0,24 \times 0,003 \times 0,890 \times 0,226 \times$ $0,199 \times 0,020 \times 1 \times 0,066 \times 0,864 \times 0,296 \times 0,017 \times 0.339 \times 0,983=$

$\mathrm{P}(\mathrm{X} \mid$ bukan penerima $)=0,923 \times 0,117 \times 0 \times 0,092 \times 0,154 \times 0 \times 0 \times 0,526 \times 0,892 \times 0,052 \times 0,926 \times$ $0,138 \times 1 \times 0,526 \times 0 \times 0,96 \times 0,218 \times 0,646 \times 0,938=0$

$\mathrm{P}(\mathrm{X} \mid$ penerima $) \times \mathrm{P}($ penerima $)=0 \times 0,481=0,000000000000000972$

$\mathrm{P}(\mathrm{X} \mid$ bukan penerima $) \times \mathrm{P}($ bukan penerima $)=0 \times 0,519=0$

Dari perhitungan diatas disimpulkan dengan data warga penerima Bantuan Pangan Non Tunai seperti diatas maka warga tersebut digolongkan dalam klasifikasi penerima Bantuan Pangan Non Tunai karena hasil probabilitas $\mathrm{P}(\mathrm{X} \mid$ penerima $)$ x $\mathrm{P}$ (penerima) lebih besar dari yang bukan penerima. 


\subsection{Simple Distribution Nä̈ve Bayes}

Hasil model distribusi Algoritma Nä̈ve Bayes dari proses data mining digunakan untuk melihat nilai probabilitas dari Algoritma Nä̈ve Bayes. Bisa dilihat nilai yang dihasilkan dari Algoritma Nä̈ve Bayes nilai class "PENERIMA" sebanyak 0,481 sedangkan class "BUKAN PENERIMA" sebanyak 0,519, ditunjukan pada gambar 1 .

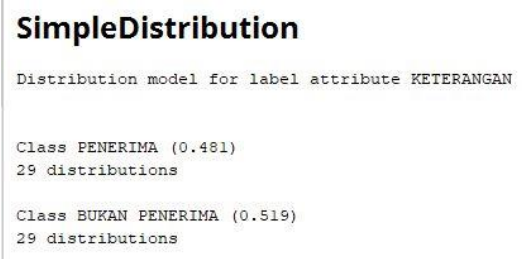

Gambar 3 Hasil Simple Distribution Algoritma Nä̈ve Bayes

\subsection{Pengujian Menggunakan Algoritma Decision Tree}

Pengujian ini dilakukan untuk mengetahui nilai Accuracy, Precision, Recall, AUC, F-Measure yang keluar serta mengetahui seperti apa hasil Pohon Keputusan yang akan di hasilkan pada proses data mining. Berikut adalah hasil pengujian menggunakan Algoritma Decision Tree dan menggunakan validasi Cross Validation. Dari Tabel 5 menunjukan bahwa Algoritma Decision Tree mendapatkan hasil Accuracy sebesar 73,97\%, Precision 85,04\%, Recall 61,92\%, AUC 0,746, FMeasure $71,17 \%$.

\begin{tabular}{|l|c|c|c|c|c|}
\hline \multicolumn{7}{|c|}{ Hasil Pengujian Algoritma Decision Tree } \\
\hline & Accuracy & Precision & Recall & AUC & F-Measure \\
\hline Algoritma Decision Tree & $73,97 \%$ & $85,04 \%$ & $61,92 \%$ & 0,746 & $71,17 \%$ \\
\hline
\end{tabular}

Gambar 4 Hasil Pengujian Algoritma Decision Tree

\subsection{Hasil Pohon Keputusan}

Hasil pohon keputusan dari proses data mining digunakan untuk melihat apa saja indikator yang berpengaruh dalam data yang telah digunakan dalam penelitian ini, hasil pohon keputusan bisa di lihat pada gambar 2.

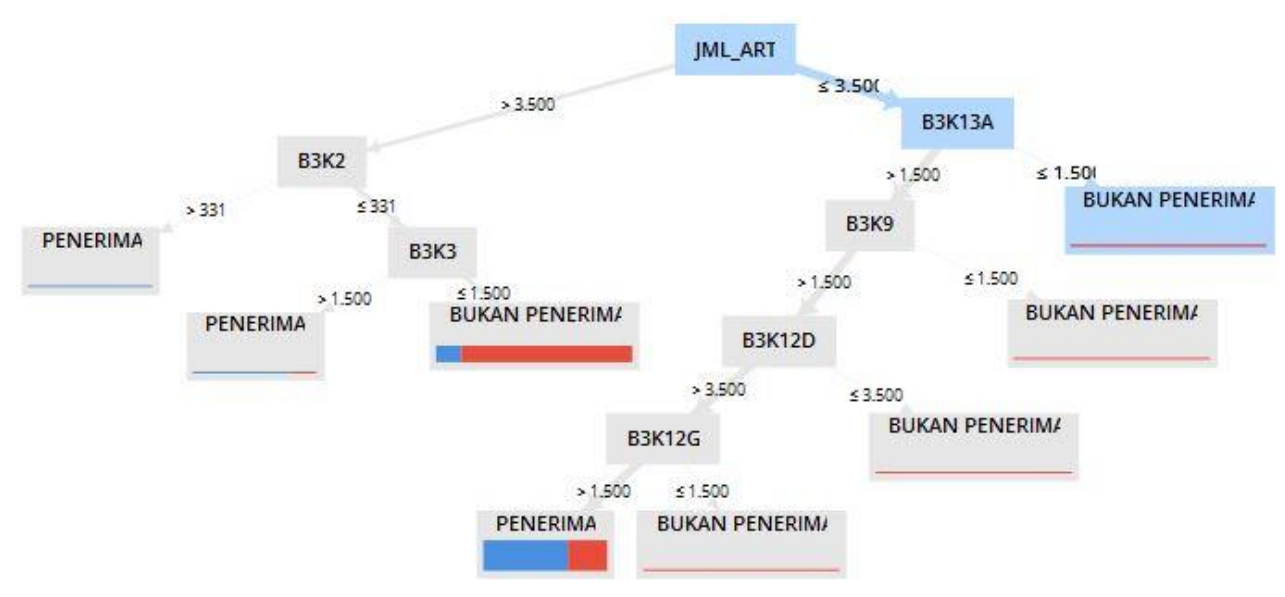

Gambar 5 Hasil Pohon Keputusan 
3.5 Perbandingan Algoritma Nä̈ve Bayes dan Algoritma Decision Tree Menggunakan T-Test

T-Test adalah metode pengujian hipotesis yang menggunakan objek penelitian dengan menggunakan dua perlakuan yang berbeda. Atau disebut juga uji beda untuk mengetahui adakah perbedaan pengujian antara 2 kelompok/pengujian menggunakan metode yang berbeda[18].

$\mathbf{H o}=$ tidak ada perbedaan hasil pengujian antara algoritma decision tree dan algoritma naïve bayes

$\mathbf{H a}=$ ada perbedaan hasil pengujian antara algoritma decision tree dan algoritma naïve bayes

Sebelum kita mentafsirkan atas hasil output maka mengetahui dasar pengambilan keputusan dalam uji t-test adapun kriteria pengujian :

Ho diterima dan Ha ditolak jika nilai sig/alpha $>0,05$

Ho ditolak dan Ha diterima jika nilai sig/alpha $<0,05$

\begin{tabular}{|l|l|l|}
\hline A & B & C \\
\hline $0.586+l-0.049$ & $0.586+l-0.049$ & $0.740+1-0.055$ \\
\hline $0.740+1-0.055$ & & 0.000 \\
\hline & \\
\hline & Gambar 6 Hasil Pengujian T-Test
\end{tabular}

Berdasarkan hasil pengujian t-test yang ada pada tabel 6. bisa di lihat, hasil pengujian penelitian ini didapat sig/alpha $=0,000$, jadi dalam penelitian ini hasilnya dapat di simpulkan signifikan/ada perbedaan pada pengujian T-Test antara Algoritma Naüve Bayes dan Algoritma Decision Tree.

\section{KESIMPULAN}

Berdasarkan hasil penelitian yang dilakukan oleh Penelitian ini maka Penelitian ini menarik kesimpulan sebagai berikut :

1. Model data mining di buat menggunakan RapidMiner, dengan hasil nilai Probabilitas untuk class "PENERIMA" yaitu 0,481 dengan pembulatan nilai menjadi 0,48 dan nilai Probabilitas untuk class 'BUKAN PENERIMA', yaitu 0,519 dengan pembulatan nilai menjadi 0,52 .

2. Berdasarkan keseluruhan pengujian dan validasi Algoritma Nä̈ve Bayes mendapatkan Accuracy sebesar 58,29\%, Precision 92,90\%, Recall 21,84\%, AUC 0,765 dan F-Measure 34,42\%, sedangkan Algoritma Decision Tree mendapatkan Accuracy sebesar 73,97\%, Precision 85,04\%, Recall 61,92\%, AUC 0,746, F-Measure 71,17\%. Dari hasil tersebut dapat dikatakan bahwa Algoritma Decision Tree lebih besar tingkat Accuracy dalam memprediksi data penerima dan bukan penerima bantuan pangan non tunai di kelurahan utama.

3. Berdasarkan hasil pengujian T-Test antara Algoritma Nä̈ve Bayes dan Algoritma Decision Tree didapat sig/alpha sebesar 0,000, maka dapat disimpulkan hasil pengujian T-Test antara Algoritma Nä̈ve Bayes dan Algoritma Decision Tree hasil nya ada perbedaan yang signifikan.

\section{SARAN}

Beberapa saran dari Penelitian ini untuk penelitian selanjutnya adalah sebagai berikut :

1. Disarankan bagi penelitian selanjutnya sebaiknya membuat aplikasi untuk klasifikasi kelayakan penerima bantuan pangan non tunai di berbagai wilayah di Indonesia.

2. Untuk mendapatkan hasil yang lebih baik lagi kedepannya perlu dilakukan pengujian dengan data yang sama atau dengan Algoritma yang berbeda, beberapa Algoritma klasifikasi seperti K-Nearest Neighbor, Neural Network, Support Vector Machine, ID3, CART, Linear Discriminant Analysis. 


\section{DAFTAR PUSTAKA}

[1] S. Nazara and S. K. Rahayu, "Program Keluarga Harapan (PKH): Program Bantuan Dana Tunai Bersyarat di Indonesia," 2013.

[2] Kementrian Sosial, "Pedoman Umum Bantuan Pangan Non Tunai," 2017.

[3] I. H. Witten, E. Frank, and M. A. Hall, Data mining. 2011.

[4] C. Orsenigo and C. Vercellis, "Multicategory classification via discrete support vector machines," Comput. Manag. Sci., vol. 6, no. 1, pp. 101-114, 2009.

[5] S. S. Nikam, "A Comparative Study of Classification Techniques in Data Mining Algorithms," Orient. J. Comput. Sci. Technol., vol. 8, no. 1, pp. 13-19, 2015.

[6] Larose, "An Introduction to Data Mining," Trad. Adapt. Thierry Vallaud, vol. 28, pp. 9-35, v, 2005.

[7] B. Santoso, Data Mining: Teknik Pemanfaatan Data untuk Keperluan Bisnis. Yogyakarta: Graha Ilmu, 2007.

[8] D. Xhemali, C. J. Hinde, and R. G. Stone, "Naive Bayes vs. Decision Trees vs. Neural Networks in the Classification of Training Web Pages," Int. J. Comput. Sci., vol. 4, no. 1, pp. 16-23, 2009.

[9] Fitriyani and R. S. Wahono, "Integrasi Bagging dan Greedy Forward Selection pada Prediksi Cacat Software dengan Menggunakan Naïve Bayes," J. Softw. Eng., vol. 1, no. 2, pp. 101-108, 2015.

[10] I. H. Witten, E. Frank, and M. A. Hall, Data Mining Practical Machine Learning Tools and Techniques. Elsevier, 2011.

[11] C. A. Sugianto, "Analisis Komparasi Algoritma Klasifikasi Untuk Menangani Data Tidak Seimbang Pada Data Kebakaran Hutan,” Techno.com, vol. 14, no. 4, pp. 336-342, 2015.

[12] T. H. Apandi and C. A. Sugianto, "Analisis Komparasi Machine Learning Pada Data Spam Sms," J. TEDC, vol. 12, no. 1, pp. 58-62, 2018.

[13] S. De Cnudde and D. Martens, "Loyal to your city? A data mining analysis of a public service loyalty program,” Decis. Support Syst., vol. 73, pp. 74-84, 2015.

[14] A. B. Rahardjo, "Penerapan Data Mining Untuk Mengklasifikasi Penerima dan Bukan Penerima Kartu Identitas Miskin ( KIM ) Kelurahan Sumurrejo Gunungpati dengan Metode Naive Bayes Classifier," 2015.

[15] H. Annur, "Klasifikasi Masyarakat Miskin Menggunakan Metode Naive Bayes," Ilk. J. Ilm., vol. 10, no. 2, p. 160, 2018.

[16] A. Z. Abidin and Y. I. Kurniawan, "Aplikasi Klasifikasi Penerima Kartu Indonesia Sehat Menggunakan Algoritma K-Nearest Neighbhor," J. INSTEK (Informatika Sains dan Teknol., vol. 4, no. 2, pp. 151-160, 2018.

[17] Y. Magfiroh, "Rekomendasi Bantuan Penerima Bantuan Iuran (PBI) Menggunakan Klasifikasi Algoritma Naive Bayes," Universitas Nusantara PGRI Kediri, 2016.

[18] Khafiizh Hastuti, "Analisis Komparasi Algoritma Klasifikasi Data Mining Untuk Prediksi Mahasiswa Non Aktif," in Seminar Nasional Teknologi Informasi \& Komunikasi Terapan 2012 (Semantik 2012), 2012, vol. 14, no. 1, pp. 241-249. 